\title{
Policies to mitigate the damage from coastal natural disasters: preparing southeastern U.S. coastal communities
}

\author{
J. Pompe \\ Economics Department, Francis Marion University, USA
}

\begin{abstract}
The combination of densely populated areas, high-valued real estate, and physical vulnerability to severe storms has led to some of the costliest natural disasters in history. In light of concerns that global warming will increase the vulnerability of coastal areas, policy approaches that can encourage sustainable development and aid coastal zone management are important. Policies that protect natural defenses, direct development away from hazardous areas, enforce storm-resistant building codes, and remove perverse incentives, will promote sustainable communities in vulnerable coastal areas.
\end{abstract}

Keywords: sustainable coastal communities, natural disasters.

\section{Introduction}

Residents of coastal areas, especially along the southeastern United States coast, have suffered through increasingly costly storms in recent years. The five most intense consecutive storm seasons on record occurred between 1995 and 2000 . An unprecedented 4 hurricanes, viz. Charley, Frances, Ivan and Jeanne, damaged Florida communities during 2004. The 2005 hurricane season was the busiest and most costly in United States history, with 28 named storms, 15 of which were hurricanes, including Katrina.

In part, recent storms have become more costly because of rapid population growth in coastal areas, which leads to the construction of more homes and businesses. NOAA's report [1] on coastal population trends in the United States shows that from 1980 to 2003 coastal population increased from 120 to 153 million people, an increase of 28 percent. Projections suggest that another 11 million people will move to coastal counties by the year 2008 for another 7 
percent increase. Much of the coastal population growth has occurred on the shorelines of southeastern and Gulf Coast states. Coastal population density of the Southeast region (Florida, Georgia, North Carolina, and South Carolina) increased from 142 to 224 persons per square mile between 1980 and 2003, and is expected to increase to 241 by 2008 [1]. The current southeast region population density is $2 \frac{1}{2}$ times the population density of the nation which is 98 persons per square mile.

The combination of densely populated areas, high-valued real estate, and physical vulnerability to severe storms has led to some of the costliest natural disasters in history. The 2004 and 2005 hurricane seasons produced seven of the ten costliest insured losses ever to affect the United States [2]. Katrina was the most costly, causing $\$ 40.6$ billion in damages and in total, the seven hurricanes caused $\$ 79.3$ billion in insured losses. Insurance companies, responding to the higher costs, have increased premiums and even withdrawn from some markets. Consequently, there has been growing pressure for increased government intervention to help coastal residents with property insurance costs.

Rising sea level and coastal erosion increase the risk from storms that coastal residents must face. Some are projecting that sea level may increase by a meter or more by 2100 [3], which will inundate some coastal areas and increase the exposure of other areas. In light of concerns that global warming and sea level rise will increase the vulnerability of coastal areas, I consider policy approaches that can encourage sustainable development and aid coastal zone management.

\section{Policies to encourage sustainable coastal communities}

Correcting human activities that contribute to the creation of more vulnerable coastal communities can help protect coastal residents and their property. For example, human created problems, such as development in hazardous areas, poorly constructed levies, and the human destruction of wetlands contributed to the Katrina disaster. Government can implement various policies to improve the likelihood of sustainable communities.

\subsection{Land-use policies to protect natural defenses}

Implementing land-use policies that balance development and ecosystem protection will lessen coastal community vulnerability to storm damage. Ecosystem management, such as protection of wetlands, which absorb some of a hurricane's impact, can reduce storm damage. Costanza, et al. [4] estimated that coastal Louisiana wetlands provided \$400/acres/year (in 2006 dollars) in storm reduction benefits. Although the Mississippi deltaic plain bordering Louisiana provides valuable storm damage reduction benefits, numerous human activities have destroyed large areas of the coastal marshes. Since 1900, about $4900 \mathrm{~km}^{2}$ of wetlands in coastal Louisiana have been lost at rates as high as $100 \mathrm{~km}^{2} /$ year.

In order to maintain and enhance Gulf Coast coastal wetlands, the federal government has undertaken a large-scale effort, which includes using dredged sediments to restore wetlands and barrier islands [5]. In addition, the team of 
researchers that produced Coast 2050 [6], a year and a half study completed in 1998, recommended that the Mississippi River be re-engineered to imitate natural processes, in order to restore wetlands. The study group estimated that re-diverting the River's flow would cost \$14 billion in 1998.

Market-incentive policies such as Wetland Mitigation Banking and the Wetland Reserve Program (WRP) help protect and restore wetlands that can help protect coastal areas. For example, the WRP, which the United States Department of Agriculture's Natural Resources Conservation administers, offers financial incentives and technical assistance to landowners to protect, restore, and enhance wetlands on their property. The WRP, which was established by the 1990 Farm Bill, offers tax incentives and payments to landowners who agree to restore previously converted wetlands. Most WRP sites are in flood prone areas [7].

Efforts to protect barrier islands, which parallel mainland areas, are important for coastal protection. Barrier islands, which absorb wave action and storm surge, provide a buffer against storms and offer a valuable habitat for fish and wildlife. The Federal government attempts to protect barrier islands and discourage development in hazardous areas through the 1982 Coastal Barrier Resource Act (CBRA). Communities in CBRA areas (certain high-risk areas on barrier islands) are restricted from receiving any federal financial assistance such as post-storm reconstruction and erosion control, in addition to National Flood Insurance Program (NFIP) insurance. Unfortunately, a 1992 review found that new development was continuing in CBRA areas and that 9 percent of the residents received NFIP insurance [8]. Increased efforts to discourage development in hazardous areas, especially the barrier islands in CRBA, should be undertaken. Government agencies involved with flood insurance should make it clear that buildings in such areas will not qualify for subsidized insurance. If such a policy is made clear prior to any construction in such areas, less development will take place since property owners risk costs would be higher.

Shoreline erosion, which is caused by natural processes and humankind projects, exposes coastal communities to increased threats. The effects of erosion may be mitigated with land-use policies that protect dunes and natural vegetation, which stabilize shorelines. Some states, for example, prohibit the destruction of vegetation on shoreline areas.

\subsection{Directing development}

Government can reduce damage from natural disasters by directing development away from undeveloped floodplains and erosion zones, as recommended by the U.S. Commission on Ocean Policy [9 , p. 168]. Although the goal of the 1968established National Flood Insurance Program (NFIP), which provides subsidized flood insurance, was to direct development away from hazardous areas, it has not been effective. With more than a third of the 6.6 million buildings located in the 100-year floodplains of participating communities built after the NFIP floodplain management plan, the program has not successfully directed development away from the path of floods [10]. 
Some states implement setback regulations that require new construction to be set back from the shoreline a minimum distance, which may be determined by erosion rate or land elevation. In South Carolina, for example, 20 feet landward of a baseline, drawn at the point of the highest ridge line of the primary dune, is the closest to the shoreline that a structure can be built [11]. Such setbacks will minimize the negative effects of erosive shorelines, sea level rise, and storm damage costs.

In those hazardous areas already developed, government can encourage relocation. For example, the property buyout program, authorized by the 1988 Stafford Act, provides federal dollars to purchase property in floodplains to reduce future expenditures from flood damage [12]. The purchased areas must not be allowed to be developed again, because this would subsidize development.

Titus [13] suggests rolling easements as a way to adapt to rising sea level. Such an approach would have the government purchase a property when sea level rose to a certain level. Because a house is removed as the shore moves toward it, the beach profile would be maintained as the shore migrated inland. A policy of "retreat" from the beach, which may involve purchasing threatened property, will be costly in most coastal areas that are developed. Parsons and Powell [14], for example, estimate that over the next 50 years, the cost of retreat for Delaware beaches would be $\$ 291$ million in present value terms. An alternative policy of beach nourishment, which would protect real estate from the erosive shoreline, would cost $\$ 60$ million for the same period.

Policies to limit population growth in hazardous coastal areas may be desirable. Impact fees, for example, could be imposed on new housing to discourage development in hazardous areas. Generally, impact fees, are meant to compensate a local government for the fiscal impact of new housing and therefore may not have much of an impact on limiting development. Limiting building permits can decrease the amount of building activity in an area. By restricting the supply of new housing, population growth may be slowed.

\subsection{Storm-resistant construction and engineering projects}

Encouraging storm-resistant construction will mitigate hurricane damage. Fronstin and Holtman [15] found that Hurricane Andrew, which struck Florida in 1992, caused less damage in subdivisions with higher average home prices. Although houses were more expensive in higher income areas, because the houses were more storm-resistant, nearby houses suffered less damage from wind-blown debris. A quarter of the $\$ 16$ billion in insured losses from Hurricane Andrew were attributed to Dade County's failure to enforce building codes [16]. Poor enforcement of building codes has been a problem in many of the southeastern states. At the time of the Gulf coast hurricanes in 2005, building codes were not enforced adequately in Alabama, Louisiana, Mississippi, and Texas [17].

Although building codes have not always been enforced, many southeastern state and county governments are improving building standards in coastal areas. Louisiana passed legislation in December of 2006 requiring the 11 parishes 
hardest hit by Katrina to begin within 90 days to meet the wind and flood provisions of the International Building and Residential Codes. This building code requires homes built along the Gulf Coast to withstand winds of 130 to 150 miles per hour. In order to meet this standard, builders will rely more heavily on steel and concrete in construction. Construction practices such as hurricaneresistant windows, metal strapping from the foundation to the roof, and houses wrapped with plywood will become commonplace [18]. In addition, houses in floodplains can be built on stilts a story above the ground to reduce storm surge damage.

Engineering technology such as the barriers the British and Dutch built to protect against North Sea storm surge are expensive but may provide an engineering option for some threatened areas. Great Britain built steel barriers across the Thames River in 1983 at a cost of 500 million pounds to protect London from storm surge. The Dutch designed the Oosterschelderkering, a huge barrier completed over two decades ago at a cost of 2.5 billion euros, south of Rotterdam [19].

Shoreline erosion, which averages two to three feet per year along Atlantic coast and six feet per year on the Gulf coasts [20], can exacerbate the threat to coastal communities. Beach nourishment, a process that pumps sand onto the beach, is a generally accepted method to mitigate shoreline erosion, although it is expensive and temporary. The average cost for a cubic yard of sand is approximately $\$ 5$. Developed states should expect to spend $\$ 6$ million per mile of shoreline each decade. In 1992, a northeaster washed away most of the sand from a 1980s $\$ 51.2$ million Ocean City, Maryland project that nourished a 9 mile stretch of beach [21]. However, in coastal areas with costly development, such costs may be justified by the storm damage reduction benefits created by wider beaches.

\subsection{Combating global warming}

Policies to combat global warming are an integral part of a program to mitigate coastal disasters. The increase in temperatures that will melt polar ice caps and cause an increase in sea level rise will inundate many coastal areas such as Miami Beach, New Orleans, and Hampton, Virginia [22]. In addition, if expectations are correct that global warming will increase hurricane intensity, occurrence, and landfall frequency [23], curbing the actions that contribute of global warming will be doubly important for many coastal residents.

Market-incentive policies offer the best hopes of success for a problem such as global warming. Marketable permits, which set a limit on allowable carbon emissions, restrict greenhouse emissions in a cost-effective manner by allowing trades between polluters. A carbon tax would levy a fee on carbon gas emissions which encourages polluters to decrease their emissions. Both incentive programs encourage least-cost solutions that are preferable to a command-and-control policy. Policies that encourage the protection and planting of forests, which absorb carbon dioxide, will help reduce carbon dioxide emissions. Credit payments for forest protection would therefore help offset the damage from greenhouse gasses. 
Policies that encourage energy efficiency, such as energy efficient buildings, will decrease fossil fuel use. Insurance companies could encourage building or rebuilding to meet "green construction" standards [24]. For example, Cementitious Structurally Insulated Panels, a technology championed by the Federation of American Scientists, has wind-resistant cladding and styrofoam cores, that provide high energy efficiency and reduces the amount of wood required for construction.

\subsection{Information on vulnerable areas}

Information about areas that are physically vulnerable should be disseminated by governments and utilized for development planning, as well as for informing residents. Agencies such as the United States Geological Service, Federal Emergency Management Agency, and the United States Army Corps of Engineers, have identified hazard-prone shorelines, based on pre-storm geomorphic factors [25]. Thieler and Hammer-Klose [26], for example, have created a physical vulnerability index for U.S. coastal areas based on six variables: 1) geomorphology, 2) shoreline erosion and accretion rates, 3) coastal slope, 4) rate of relative sea-level rise, 5) mean tidal range, and 6) mean wave height. Areas with high-energy coastlines, a low regional coastal slope, and where the major landform type is a barrier island, are the most vulnerable, generally [26]. Based on this analysis, sections of the mid-Atlantic coast (Maryland south to North Carolina) and northern Florida, are some of the areas of greatest vulnerability.

In addition, some areas are more susceptible to storm strikes. The greatest likelihood of severe damage from hurricanes is along the coastlines of the southeastern Atlantic and Gulf of Mexico states, where 112 major hurricanes have struck between 1851 and 2006 [27]. Although predictions of where the next major storm will hit are problematic, clearly some locations are more prone to suffer from storms than are others. Historically, 39 percent of all major hurricanes in the United States have battered Florida, and 71 percent of category 4 or 5 hurricane strikes have pummeled either Florida or Texas.

\subsection{Removing perverse incentives}

Unfortunately, numerous well-meaning government policies, such as the NFIP, that subsidize coastal development contribute to the problem. Removing perverse incentives that encourage development in hazardous coastal areas will reduce storm damage costs and create more sustainable communities. The NFIP, which provides subsidized flood insurance, was meant to ensure that most residents in high hazard areas were insured and to direct development away from the most flood-prone areas. It is clear that the program has accomplished neither goal. Indeed, subsidizing insurance, which encourages development in hazardous areas, has been counter-productive. In addition to subsidizing coastal development in hazardous areas, the NFIP is not actuarially sound, insurance penetration rates are low, and repetitive-loss properties absorb a large percentage of payments $[28,5]$. 
Government should minimize involvement in property insurance markets in order to avoid crowding out more efficient market solutions. Instead, the government should facilitate the development of private market solutions that will insure that those who choose to live in high-risk areas, will pay the cost of such a choice. A benefit of privately provided insurance is that companies base rates on risks involved, and thus rates will be high if risk is high. Risk-based rates encourage investment in cost-effective risk mitigation measures, such as fortified buildings, because companies will lower rates on construction that is less likely to be damaged. In addition, because rates will be highest in the most hazardous areas, residents will be less likely to locate in such areas. If insurance rates become too much of a burden for low-income families living in hazardous areas, rather than offering subsidized flood insurance, a voucher similar to food stamps could be issued. Although the homeowner would pay a risk-based premium, policy-makers could base the magnitude of the voucher on the income and assets of the resident.

In addition, government lowers the cost of residents who choose to locate in hazardous areas by paying some or all of the cost of beach nourishment, public infrastructure replacement, and disaster relief. For example, the federal government pays for much of the cost of many beach nourishment projects. Although benefits may be greater than the costs of such projects in areas where valuable property is threatened, government provided funding encourages development. Disaster relief and other government programs (such as subsidized insurance rates) that bail out people from all disasters, however well intentioned, encourage more risky choices that lead to repeat disasters. By subsidizing coastal areas with such programs, government creates a "moral hazard" which makes a full-blown disaster more likely. A moral hazard is created when an individual has no incentive to guard against a risk if already protected from the risk. Indeed, individuals have little interest in avoiding building in a hazardous area if someone else incurs the cost.

If government chooses to help residents withstand the damage from severe storms, policies that encourage spending on mitigation measures would be the more efficient than lowering insurance premiums. For example, in 2007, South Carolina legislators passed new legislation that offered tax credits for building supplies that made homes storm resistant and insurance premium discounts for residents who made homes storm resistant [29]. Such policies encourage storm resistant homes, which will reduce damage costs, and reward choices that decrease damage costs from hurricanes.

\section{Summary}

Residents in many coastal areas are subject to natural threats such as hurricanes, northeasters, and coastal erosion that may threaten community sustainability. Discontinuing programs such as the NFIP that create perverse incentives which encourage development in hazardous areas, will create more efficient and equitable results. In order to create sustainable development, land-use policies that protect natural areas such as wetlands, will balance development with 
ecosystem protection. Factoring the storm damage reduction benefits of ecosystems, such as wetlands, into benefit-cost analyses would encourage protection of valuable natural defenses. Other solutions discussed above include providing better information on vulnerable areas, encouraging storm-resistant construction, examining engineering technology, and implementing policies to combat global warming.

Cicin-Sain and Knecht [30] and others have suggested that integrated coastal management (ICM), which emphasizes the interrelationship between inland areas, coast, and ocean, is necessary to protect coastal areas. ICM requires interdisciplinary, intergovernmental, and international cooperation on policy solutions. Population growth is likely to continue along coastlines worldwide, increasing the importance of considering the problems that coastal communities must address.

\section{References}

[1] Crossett, K.M., Culliton, T.J., Wiley, P.C., \& Goodspeed, T.R., Population Trends Along the Coastal Untied States: 1980-2008. National Oceanic and Atmospheric Administration, NOAA's National Ocean Service, Special Projects: Silver Spring, MD, 2004.

[2] Insurance Information Institute. Hurricane and Windstorm Deductibles. 2007. www.iii.org/media/hottopics/insurance/hurricanwindstorm/

[3] Kerr, R.A., Pushing the scary side of global warming. Science, 316 (5830), pp. 1412-1415, 2007.

[4] Costanza, R., d'Arge, R., de Groot, R., Farber, S., Grasso, M., Hannon, B., Limburg, K., Naeem, S., O'Neill, R. V., Paruelo, J., Raskin, R. G., Sutton, P., \& Van der Belt, M., The value of the world's ecosystem services and natural capital. Ecological Economics. 25 (1), pp. 3-15, 1998.

[5] Day, J.W., Jr., et al., Restoration of the Mississippi Delta: lessons from Hurricanes Katrina and Rita. Science 23, 315, (5819), pp. 1679-1684, March 2007.

[6] Louisiana Coastal Wetlands Conservation and Restoration Task Force and the Wetlands Conservation and Restoration Authority. Coast 2050: Toward a Sustainable Coastal Louisiana. Louisiana Department of Natural Resources. Baton Rouge, La., 1998.

[7] National Resources Conservation Service. Farm Bill 2002: Wetlands Reserve Program. United States Department of Agriculture, Washington, D.C., September 2004.

[8] United States General Accounting Office (US GAO). Coastal barriers: Development occurring despite restrictions. Washington, D.C., 1992.

[9] U.S. Commission on Ocean Policy. An Ocean Blueprint for the 21st Century. Washington, DC, 2004.

[10] Burby, R.J., Flood insurance and floodplain management: the U.S. experience. Environmental Hazards 3, 3: pp. 111-122, 2001.

[11] South Carolina Beachfront Management Act. SC 49-39-250, 1988. 
[12] Pasterick, E. T., The National Flood Insurance Program. Paying the Price: The Status and Role of Insurance Against Natural Disasters in the United States. Howard Kunreuther and Richard J. Roth, Sr., eds., Joseph Henry Press: Washington, DC, 1998.

[13] Titus, J. G., Rising seas, coastal erosion, and the takings clause: how to save wetlands and beaches without hurting property owners. Maryland Law Review, 57, (4), pp. 1279-1399, 1998.

[14] Parsons, G. R. \& Powell, M., Measuring the cost of beach retreat. Coastal Management, 29, (2), pp. 91-103, 2001.

[15] Fronstin, P. \& Holtman, A.G., The determinants of residential property damage caused by Hurricane Andrew. Southern Economic Journal 61, pp. 387-97, 1994.

[16] Building Performance Assessment Team, Preliminary Report in Response to Hurricane Andrew, Dade County, Florida. Federal Emergency Management Agency: Washington, 1992.

[17] Burby, R. J., Hurricane Katrina and the paradoxes of government disaster policy: bringing about wiser governmental decisions for hazardous areas. Annals of the American Academy of Political and Social Science 604, pp.171-192, 2006.

[18] McLeister, D. Lessons from Katrina: better building, codes, materials. July 7: 2, 2007. www.hgtvpro.com/hpro/nws_dstr_huric_torndo/article/0,2624, HPRO_265224503255,00.html

[19] Barnet, J. \& Hill, K., Design for rising sea levels. Harvard Design Magazine 27, Fall 2007/Winter 2008.

[20] Baish, S., Dunn, S. \& Friedman, R., Coastal erosion: evaluating the risk. Environment, 22, (7), pp. 36-45, 2000.

[21] Trebanis, A. C., Pilkey, O. H. \& Valverde, H.R., Comparison of beach nourishment along the U.S. Atlantic, Great Lakes, Gulf of Mexico, and New England shorelines. Coastal Management, 27, pp. 329-340, 1999.

[22] Mazria, E. \& Kershner, K., Nation under Siege: Sea Level Rise at our Doorstep. The 2030 Research Center, 2007.

[23] Trenberth, K. E. Warmer oceans, stronger hurricanes. Scientific American, July, pp. 45-51, 2007.

[24] Mills, E. \& E. Lecomte, From Risk to Opportunity: How Insurers Can Proactively and Profitably Manage Climate Change. Ceres: Boston, MA, 2006.

[25] Young, R., The high cost of subsidized coastal development. Geotimes February 2006. /E:/flood\%20insurance/young.subcoast.2006.htm\#author

[26] Thieler, E. R. \& Hammar-Klose, E.S., National Assessment of Coastal Vulnerability to Sea-Level Rise: Preliminary Results for the U.S. Atlantic Coast. U.S. Geological Survey, Woods Hole: Massachusetts, 1999.

[27] Blake, E. S., Rappaport, E.N., \& Landsea, C.W., The Deadliest, Costliest, and Most Intense United States Tropical Cyclones from 1851 to 2006 (and Other Frequently Requested Hurricane Facts). NOAA Technical Memorandum NWS TPC-5. Miami: National Weather Service, 2007. 
[28] Jenkins, W. O., Jr. Federal Emergency Management Agency: Challenges Facing the National Flood Insurance Program. GAO-06-174T. Washington, DC: U.S. General Accounting Office, 2005.

[29] Faber, J., See how the State's new coastal insurance law could affect your wallet. The Island Packet, Hilton Head Island, SC, June 18, 2007. www.islandpacket.com/news/local/story/6554778p-5833850c.html

[30] Cicin-Knecht, B. \& Knecht, R., Integrated Coastal and Ocean Management: Concepts and Practices. Island Press: Washington, D.C., 1998. 